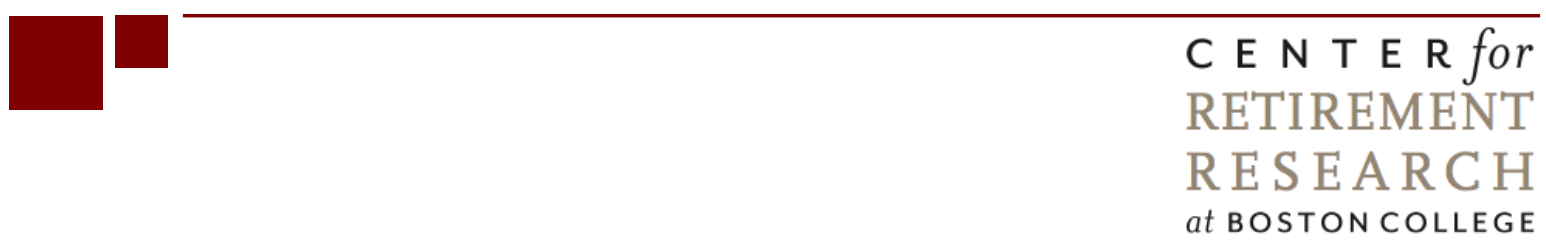

\title{
REFORMING THE RAILROAD RETIREMENT SYSTEM
}

\author{
Steven A. Sass \\ CRR WP 2013-13 \\ Released: June 2013 \\ Center for Retirement Research at Boston College \\ Hovey House \\ 140 Commonwealth Avenue \\ Chestnut Hill, MA 02467 \\ Tel: 617-552-1762 Fax: 617-552-0191 \\ http://crr.bc.edu
}

Steven A. Sass is the program director of the Financial Security Project at Boston College, an initiative of the Center for Retirement Research. The research reported herein was pursuant to a grant from the Burlington Northern Santa Fe Railway Company, CSX Corporation Inc., Norfolk Southern Corporation, and Union Pacific Corporation. The findings and conclusions expressed are solely those of the author and do not represent the views of the Burlington Northern Santa Fe Railway Company, CSX Corporation Inc., Norfolk Southern Corporation, and Union Pacific Corporation, or Boston College.

(C) 2013, Steven A. Sass. All rights reserved. Short sections of text, not to exceed two paragraphs, may be quoted without explicit permission provided that full credit, including $\odot$ notice, is given to the source. 


\begin{abstract}
About the Center for Retirement Research
The Center for Retirement Research at Boston College, part of a consortium that includes parallel centers at the University of Michigan and the National Bureau of Economic Research, was established in 1998 through a grant from the Social Security Administration. The Center's mission is to produce first-class research and forge a strong link between the academic community and decision-makers in the public and private sectors around an issue of critical importance to the nation's future. To achieve this mission, the Center sponsors a wide variety of research projects, transmits new findings to a broad audience, trains new scholars, and broadens access to valuable data sources.
\end{abstract}

\author{
Center for Retirement Research at Boston College \\ Hovey House \\ 140 Commonwealth Avenue \\ Chestnut Hill, MA 02467 \\ phone: 617-552-1762 fax: 617-552-0191 \\ e-mail: crr@bc.edu \\ crr.bc.edu
}

Affiliated Institutions:

The Brookings Institution

Massachusetts Institute of Technology

Syracuse University

The Urban Institute 


\section{A QUICK PRIMER ON RAILROAD RETIREMENT}

The railroads were the first U.S. companies to make pensions a standard feature in their personnel management systems. Company plans covered 80 percent of the industry work force by the end of 1920s, about half of all workers in the private sector covered by a plan. While prefunding came to be recognized in the 1920s as "best practice" pension plan management, the railroads had become a financially weak industry and continued to operate their plans on a payas-you-go basis. Burdened with high fixed costs and the emergence of intercity truck completion, the railroads entered the Depression with unfunded plans paying benefits to 50,000 beneficiaries. ${ }^{1}$

As the burdens of pension payments stressed the carriers' fragile finances, a grassroots organization of rail workers - from retirees seeking to secure their pensions to young workers seeking to keep their jobs by retiring their elders - turned to the federal government. The rail workers were numerous, dispersed throughout the nation, and politically influential; the railroads were heavily regulated and long seen as a critical national industry; and the Depression was a national economic emergency. So the rail workers succeeded in having Congress nationalize the carrier's plans, in 1934. Like the Social Security program enacted one year later, the federal Railroad Retirement program was funded on a pay-as-you go basis with equal employer and employee contributions. And because rail workers had this plan, they were excluded from Social Security. ${ }^{2}$

In the postwar period, Congress expanded benefits to keep pace with benefits provided by Social Security (adding spousal and survivor benefits) and benefits negotiated in collectively bargained plans (adding early retirement on full benefits and occupational disability, which grants disability benefits if the worker can work, but not in his or her current occupation). Funding nevertheless remained pay-as-you-go. And the railroads remained financially weak, with rapidly declining employment. ${ }^{3}$

In 1974, the same year Congress 'rationalized' employer plans with the Employee Retirement Income Security Act (ERISA), it rationalized Railroad Retirement. It divided the program in two, with Tier 1 essentially replicating Social Security and Tier 2 clearly identified as

\footnotetext{
${ }^{1}$ Sass (1997); U.S. Railroad Retirement Board (2010).

${ }^{2}$ While the 1934 legislation was declared unconstitutional by the Supreme Court, revised legislation passed muster. Sass (1997); Whitman (2008); U.S. Railroad Retirement Board (2010).

${ }^{3}$ Stover (1997); Winston (2006); Salmon (2013).
} 
the industry's supplementary “employer" pension program. Tier 1 taxes and benefits would now be transferred to and from the Social Security Trust Fund, making Railroad Retirement Tier I in essence a "pass-through." The legislation also reduced the employee tax to the Social Security tax, with amounts needed for benefits above Social Security payments borne by the carriers alone. Where each had paid 10.6 percent of covered earnings, employees now paid 5.85 percent and employers 15.35 percent - with 5.85 percent sent to Social Security and 8.5 percent retained by Railroad Retirement. ${ }^{4}$

The Railroad Retirement program retained the obligation to pay certain sweetened Social Security benefits, known as "Excess Tier I" benefits. Most important was “60/30” - a new provision in the 1974 legislation that allowed workers age 60 with 30 years of service to retire on unreduced benefits - unreduced Tier 1 (Social Security) benefits as well as unreduced Tier 2 benefits. The legislation did eliminate future windfall "dual" benefit entitlements, which had allowed rail workers who qualified for Social Security benefits based on non-railroad work to get unusually high "Social Security" benefits, paid for by Railroad Retirement. ${ }^{5}$ Despite the elimination of future dual entitlements, the 1974 legislation's addition of 60/30 increased the program's obligations.

The shift in the payroll tax from workers to employers exacerbated the serious financial pressures on U.S. railroads. Over 20 percent of the nation's rail mileage, including the iconic Penn Central would enter bankruptcy in the 1970s. Assets in the Railroad Retirement Trust Fund also fell sharply, from three times annual benefit payments in 1970 to barely an eight month cushion in 1979. Both the industry and its retirement program thus ended the decade financially distressed. ${ }^{6}$

\footnotetext{
${ }_{5}^{4}$ U.S. Railroad Retirement Board (2009 and 2010); Whitman (2008); Salmon (2013).

${ }^{5}$ The windfall dual benefit had been an inadvertent result of Social Security's procedure of basing benefits on the average of a worker's indexed earnings over all years since 1950 (or highest 35 years after 1985). Ten years of employment covered by Social Security was needed to qualify for benefits. But earnings from ten or more years of non-railroad work would be averaged over all years since 1950, making the worker appear like a lower earner. As Social Security replaced a much larger share of a low earner's wages, this procedure had provided rail workers a benefit that replaced a high percentage of those average earnings, and a very generous benefit for relatively few years of covered employment.

${ }^{6}$ Stover (1997); Winston (2006); See Figure 1.5, below.
} 


\section{BACKGROUND FOR REFORM: THE 1980s WATERSHED}

The 1980s marked a watershed in the finances of the railroad industry, setting the stage for initiatives that would result in the creation of a reformed railroad retirement system and the NRRIT. The key events were the Staggers Act in 1980; the shoring up of railroad retirement finances, primarily in legislation enacted in 1983; and a management proposal to privatize railroad retirement, which would evolve into an initiative to invest railroad retirement assets as assets are invested in private plans.

The Staggers Act of 1980 was part of a broader initiative that loosened federal regulation of the nation's major transportation systems -the Airline Deregulation Act of 1978, the Motor Carrier Act of 1980, and the Staggers Act for railroads. Deregulation ushered in a dramatic decline in railroad rates - rates on average were cut in half - and a dramatic rise in railroad profits (Figure 1.1). The explanation was a dramatic rise in productivity due to industry consolidation, the abandonment of uneconomic lines, the growth of long-haul coal and intermodal traffic, and a far more intensive use of a "right-sized" railroad system. ${ }^{7}$

Figure 1.1. Rail Industry Return on Investment: Before and After the 1980 Staggers Act

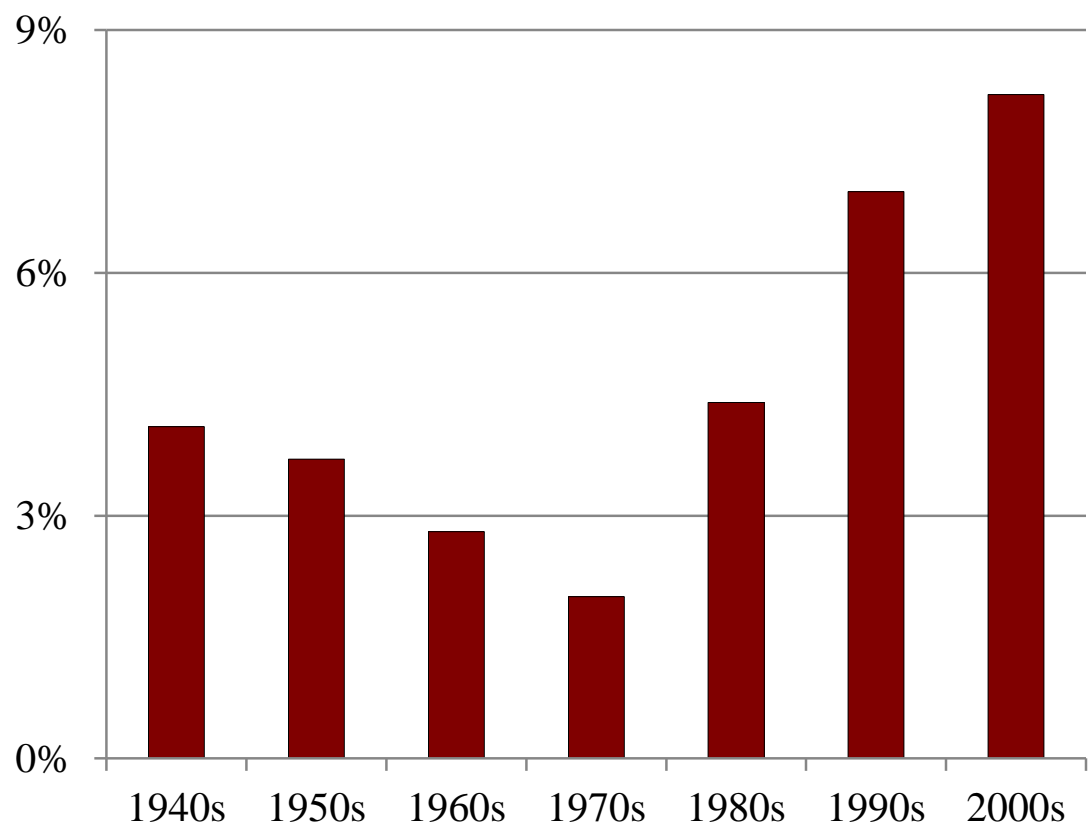

Source: Association of American Railroads (2011).

\footnotetext{
${ }^{7}$ Stover (1997); Caves, Christensen, and Swanson (2010-11).
} 


\section{SHORING UP RAILROAD RETIREMENT}

While the Staggers Act rejuvenated the railroads, it inadvertently undermined the fragile finances of the industry's retirement program. Railroad Retirement was a pay-as-you-go plan, with benefits financed by a tax on current payroll. The ratio of beneficiaries to workers is critical to the health of such programs, and by 1980 the ratio had become decidedly worrisome. The number of beneficiaries had more than doubled since 1950 while the number of workers had declined by well over half. So taxes on each active worker in 1980 funded the benefits of 2 beneficiaries, up from just 0.3 in 1950. The decline in railroad employment had nevertheless slowed in the 1970s while the number of beneficiaries, which is relatively predictable, would slowly plateau and then trend down. But the efficiencies Staggers introduced accelerated the decline in railroad employment. By the end of the 1980s, taxes on each active worker would need to pay the benefits of 3.2 beneficiaries (Figure 1.2).

Figure 1.2.a Railroad Retirement Beneficiaries and Active Railroad Employment, 1950 to 1990. (thousands)

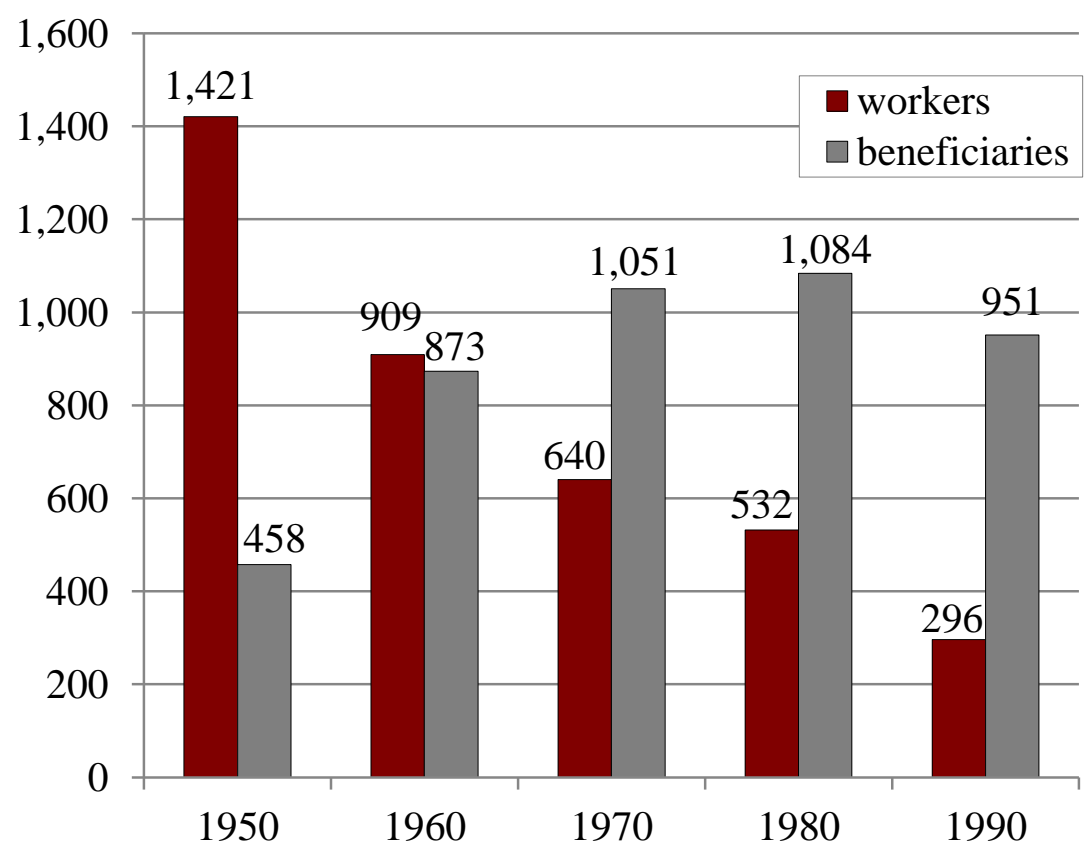

Source: U.S. Railroad Retirement Board Annual Reports, various years. 
Figure 1.2.b Ratio of Railroad Retirement Beneficiaries to Active Employees, 1950 to 1990.

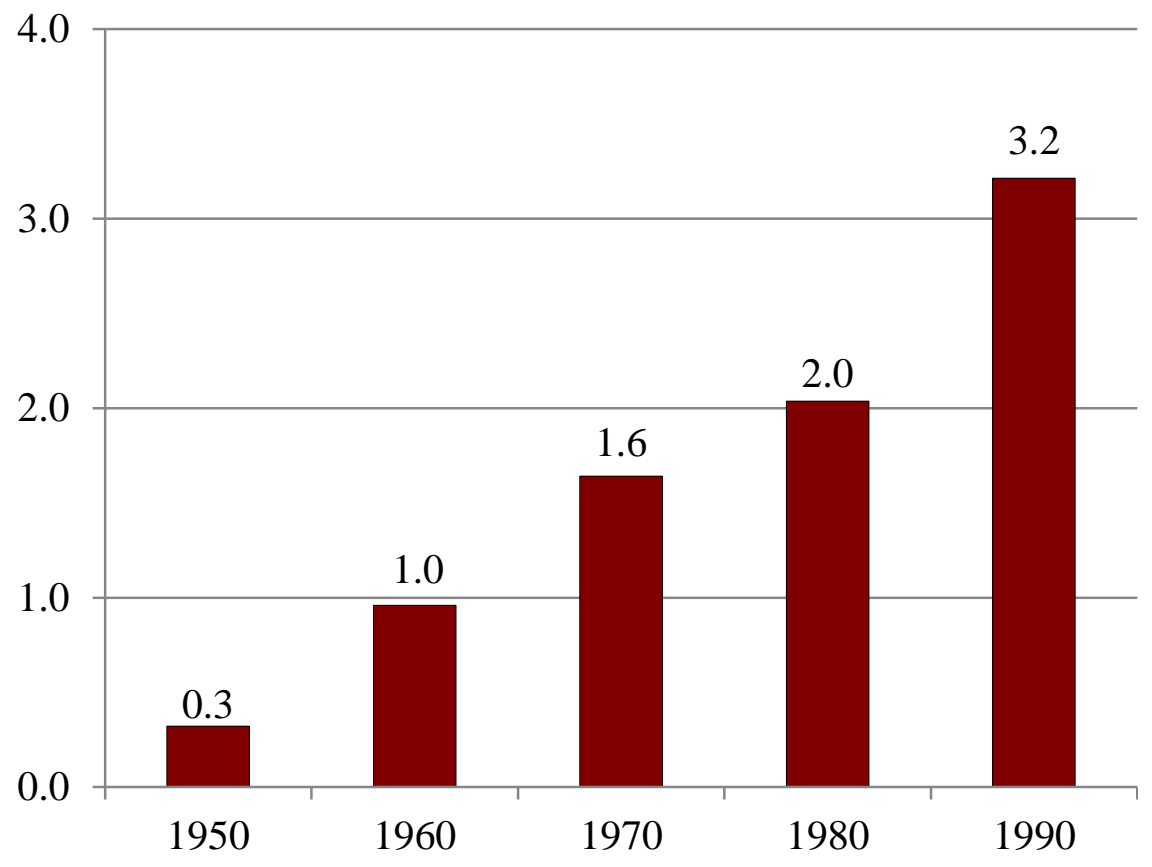

Source: Data from U.S. Railroad Retirement Board Annual Reports, various years.

Congress responded to the rising ratio of beneficiaries to workers in 1981, raising the tax on employers from 9.5 to 11.75 percent of payroll and initiating a 2 percent tax on workers. The accelerated decline in railroad employment would in time require higher taxes or lower benefits. But the sharp recession of 1980-82 brought the crisis on much sooner. Rail employment fell below 400,000 in 1983, a 25 percent decline from its level in 1980, and the Railroad Retirement Board, the government agency responsible for managing the program, was considering a 40 percent cut in benefits. ${ }^{8}$

As it turned out, 1983 was the year Congress enacted a major reform of the Social Security program, significantly raising taxes and cutting benefits to address a significant funding shortfall. Immediately after completing work on Social Security, the House Committee on Ways and Means turned to Railroad Retirement. Seeing parallels with Social Security, Ways and Means drafted a bill that significantly raised Railroad Retirement taxes and cut Railroad Retirement benefits. The legislation increased the payroll tax nearly 40 percent over three years, from 13.75 to 19 percent of payroll, raising the tax on workers to 4.25 percent and the tax on carriers to

\footnotetext{
${ }^{8}$ Commission on Railroad Retirement Reform (1990) p. 275; Legislation enacted in 1981 had mandated a cut in benefits should the program have insufficient revenues. U.S. Railroad Retirement Board (2009) p. 7.
} 
14.75 percent (Figure 1.3). It also cut benefits. It eliminated 60/30 - retirement at age 60 on unreduced Tier 1 benefits for workers with 30 years of service - requiring workers with 30 years of service to be at least age 62 to retire on unreduced Tier 1 benefits. It also eliminated Tier 2 survivor benefits, providing widow(er)s just a continuation of much lower spousal benefits. ${ }^{9}$ Further bolstering the program, and also similar to the 1983 Social Security reform, the legislation subjected Railroad Retirement benefits to income taxation and returned the proceeds to the Railroad Retirement Trust Fund. ${ }^{10}$ Section 502 of the legislation also called for the Railroad Retirement Actuary to submit an annual report on the program's finances. Unlike most prior and subsequent reforms of the system, the 1983 changes were not the result of a labormanagement joint initiative, but proposals imposed by Congress to address the severe financial crisis.

While the U.S. economy recovered strongly from the sharp recessions of the early 1980s, continued sharp declines in railroad employment renewed concerns over the finances of the Railroad Retirement program. The Office of Management and Budget proposed another large tax increase, with rail management and labor responding by negotiating a compromise. Congress would raise the payroll tax another 10 percent, to 21 percent of payroll, with the tax on workers rising to 4.9 percent and the tax on carriers to 16.1 percent (Figure 1.3), and it would create a Commission to examine the long-run financing of the program, including a review of other funding options.

\footnotetext{
${ }^{9}$ Spouses had been entitled to "spousal benefits" when the worker was alive and "survivor benefits" upon widowhood. Tier 2 spousal benefits were 45 percent of the worker's Tier 2 benefit and the survivor benefit was the worker's actual Tier 2 benefit. Tier 2 benefits were partially indexed to inflation - increased by 32.5 percent of the increase in prices - and thus also lost significant value by the time most spouses became widows.

${ }^{10}$ Prior to the 1983 Acts, neither Social Security nor Railroad Retirement benefits were taxed. Commission on Railroad Retirement Reform (1990), 120 ff.
} 
Figure 1.3. Railroad Retirement Tier 2 Tax Rate, 1975 to 1988

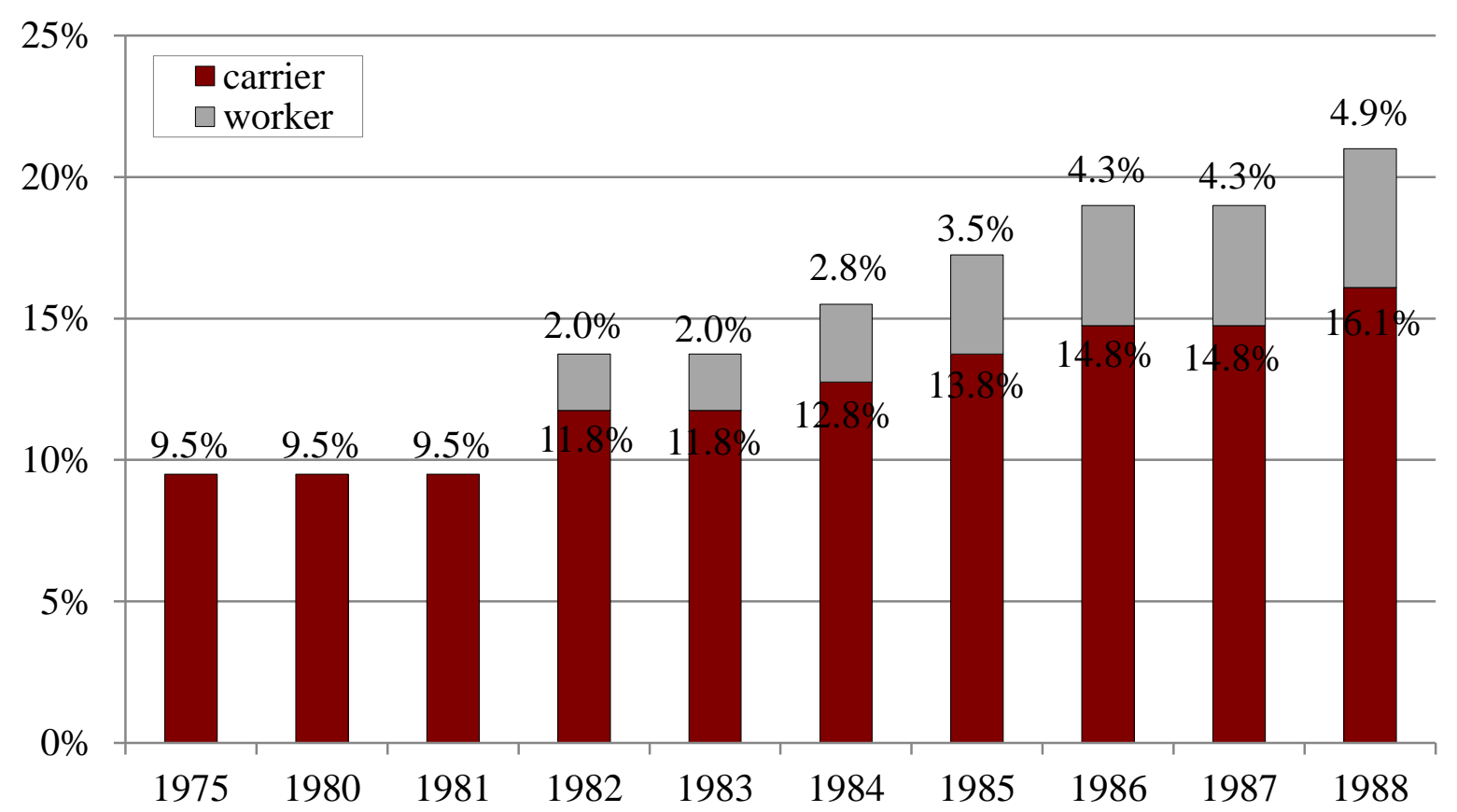

Source: U.S. Railroad Retirement Board (various years).

In less than a decade, the payroll tax had gone from 9.5 percent of payroll, paid entirely by the carriers, to 21 percent of payroll, with the carriers paying 16.1 and workers 4.9 percent. It had gone from an annoyance to what Drew Lewis, Chairman of the Union Pacific, called the industry's "foremost legislative concern" - a concern that would result in a major reform of the Railroad Retirement program. ${ }^{11}$

\section{THE APPEAL OF PRIVATIZATION FOR RAIL MANAGEMENT}

The government-run Railroad Retirement program is a clear anomaly in the U.S. economic landscape. In the late 1980's, there were many in government who would gladly returned the program, with its financial, administrative, and political burdens, back to the private sector. The Office of Management and Budget even drafted a bill in 1988 to do just that. As the fortunes of the railroads revived in the 1980s, and as the Railroad Retirement payroll tax exploded, officials in Lewis's Union Pacific also grew interested in reform. They saw investing Railroad Retirement assets in equities as a way to reduce the cost of the program, and privatization as the

\footnotetext{
${ }^{11}$ Salmon (2013).
} 
only way this could be done. And by the late 1980s, officials in the Union Pacific tax department had sketched out a plan. ${ }^{12}$

Privatization was complicated. Would existing workers and beneficiaries be transferred to the new private program? Would a privatized program retain unique "government" features, specifically the return of income taxes on benefits? Could the industry extract a price from the federal government for assuming this liability, especially liabilities it viewed as unfair impositions, such as windfall dual benefits? How would the program be managed? And how would the transition occur? ${ }^{13}$

The Union Pacific plan of the late 1980s was hardly fully developed. But the outlines were clear. It would establish a standard collectively bargained multi-employer plan for new hires while existing workers and beneficiaries would remain in a "legacy Tier 2" program. The assets of the new plan would be invested as the assets in any private plan; the assets of the legacy program would continue to be invested in government bonds. The return of income taxes on Railroad Retirement benefits would continue. And the government would pay "restitutions" for the unfair burdens it had imposed in the past on the Railroad Retirement program. The plan would also continue current tax/contribution rates, on both new and existing workers, with amounts in excess of ERISA funding requirements for the plan for new hires "taxed" and transferred to the legacy Tier 2 program. When the legacy program was "fully funded" - when assets in its Trust Fund equaled the present value of legacy Tier 2 obligations - the transition to a privatized Railroad Retirement would be complete.

Key elements of the Union Pacific design won the endorsement of the Commission on Railroad Retirement Reform, established in the 1987 legislation. The Commission's 1990 report, however, also included recommendations opposed by the carriers (a change in the way payroll taxes were calculated) and labor (cuts in early retirement benefits and a more stringent disability program). As neither management nor labor supported the Commission's package of reforms, the industry did not approach Congress urging enactment of its recommendations. As

\footnotetext{
${ }^{12}$ For a description of the Office of Management and Budget plan see Commission on Railroad Retirement Reform (1990) pp. 186-188; interview with Randy Weiss; a version of the Union Pacific plan was also presented to the Commission by the "Regional Railroads of America."

${ }^{13}$ For a discussion of these complications, see Commission on Railroad Retirement Reform (1990) pp. 184-200.
} 
the Commission also declared Railroad Retirement financially healthy, there was no need for action. So the Commission's recommendations were never considered by Congress. ${ }^{14}$

The appeal of privatization neverthess persisted in the tax department of the Union Pacific and with senior tax professionals at other railroads. The focus at the Union Pacific was to lower the cost of the program. Others in the industry saw the program producing large future surpluses, which would be costly and invite demands from labor for increased benefits. ${ }^{15}$ However, senior management in some of the railroads and the staff in the industry trade association, the Association of American Railroads (AAR), were cautious. Going to Congress was risky. Their dominant concerns, moreover, were mergers then consolidating the nation's major freight carriers into four giant roads, and the resulting complications in relations with unions and government regulators. In time, the mergers would simplify the task of forming a carrier consensus on reforming Railroad Retirement, by reducing the number of major players in the industry. But launching a major initiative to privatize the pension program, while the mergers were underway, would only complicate these high-stakes maneuvers, especially with labor. $^{16}$

In 1995, a pathway forward opened. The Social Security Advisory Council was then considering major reforms to close Social Security's long-term financing shortfall, including "privatization" measures such as the creation of individual accounts and the investment of Social Security Trust Fund assets in equities. Any such reform would likely affect government policy on Railroad Retirement. So rail industry tax officials used this development to pressure the AAR to develop a process to review the carrier's position. Like most industry trade associations, the AAR was risk adverse and reticient to take on controversial initiatives without broad support. But given the attention on Social Security reform, the AAR authorized the development of an updated industry position on Railroad Retirement in January $1995 .{ }^{17}$

Responsibility for developing the industry position fell to the AAR Tax Policy Committee, led by Jim Hixon of the Norfolk Southern. Hixon in turn organized a Tax Working Group (TWG) to develop a plan. The group's key members included Hixon, the Union Pacific's Bernie Gutschewski, Jim Peter of CSX, Dan Westerbeck of what would become BNSF, and two

\footnotetext{
${ }^{14}$ For the Commission's recommendations, see Commission on Railroad Retirement Reform (1990) pp. 2-15. Also see Salmon (2013), pp. 12-13.

${ }^{15}$ Interview with James Hixon.

${ }^{16}$ Salmon (2013), pp. 19-20.

${ }^{17}$ Salmon (2013), pp. 12.
} 
key contributors to the Union Pacific's work on Railroad Retirement - lawyer John Salmon of Dewey Ballantine and economist Randy Weiss of Deloitte \& Touche, as the Group's key members.

The TWG essentially adopted the Union Pacific plan, adjusted to function as the opening position in a negotiation. The proposal it developed, for example, would transfer to the government "excess Tier 1" benefits - benefits based on the Social Security benefit formula but far more generous than what Social Security provides. Excess Tier 1 benefits were expensive. They included items such as retirement on full benefits at age 62 with 30 years of service, as opposed to full benefits only available at Social Security's "Full Retirement Age" of 65; and “occupational" disability, which granted benefits to workers unable to perform their occupational tasks, even if capable of working in some other occupation. The working group knew the government would likely balk at the transfer. But it wanted to remove this touchy issue in any initial negotiations with labor, which would inevitably come before any negotiation with the government, to clear the decks to discuss privatizing the Tier II program. And there was always the outside chance that the government might accept a portion of these benefit obligations. ${ }^{18}$

\section{COURTING LABOR}

The path forward again opened in 1997. As part of an interim compromise in a contenious dispute over occupational disabilty benefits, the rail unions had agreed to meet with management "to discuss ... Railroad Retirement issues." The meeting took place during a break in the scheduled program at rail labor's winter meetings. At that meeting, Hixon and Salmon from the TWG highlighted threats to the status quo - initiatives to reform Social Security, the shift from traditional employer pensions to 401(k)s, and the high cost of the Railroad Retirement program. And they explained the virtues of privatization - how the higher returns on assets could lower the program's cost, and the taxes paid by labor and management. The assembled union officials sat through the presentation and, by prior agreement among themselves, made no comments and left the room without asking any questions. ${ }^{19}$

\footnotetext{
${ }^{18}$ Salmon (2013), pp. 12-18.

${ }^{19}$ Salmon (2013), p.21-23; Tax Working Group (1995).
} 
Labor had little interest in management's proposal. The carrier's primary interest in Railroad Retirement was cost, and the primary argument for privatization in the TWG presentation was a reduction in cost. Labor's primary interest was benefit security. Railroad Retirement benefits were statutory, defined in an Act of Congress. The law stipulated that benefits would be cut if revenues were insufficient. But the program was financially sound, the carriers paid most of the bill, and labor was confident that Congress would shore up the program if need be. Labor was also concerned that going to Congress with such a radical proposal risked a review of the existing benefit package, specifically excess Tier 1 benefits that the 1990 Commission on Railroad Retirement Reform had recommended be eliminated. So labor saw no reason to accept a modest tax cut in exchange for the far less certain benefits of a private plan and risk revisions in the legacy program. ${ }^{20}$

The one element in management's presentation that did appeal was the investment of Trust Fund assets in equities. Most union pension funds invested in equities. Equities had been stellar performers over the past two decades, with annual returns averaging over 13 percent above inflation ${ }^{21}$ (Figure 1.4). So while "past performance is no guarantee of future performance," many union officials were quite comfortable with investing Railroad Retirement assets in equities. ${ }^{22}$

\footnotetext{
${ }^{20}$ Tax Working Group (1995); interview with Joel Parker.

${ }^{21}$ Geometric average return over the period 1980 to 1999 . The arithmetic average was 14.7 percent above inflation.

${ }^{22}$ Interview with Joel Parker.
} 
Figure 1.4. Real Return on Equities, 1980-1999, Large Company Stocks

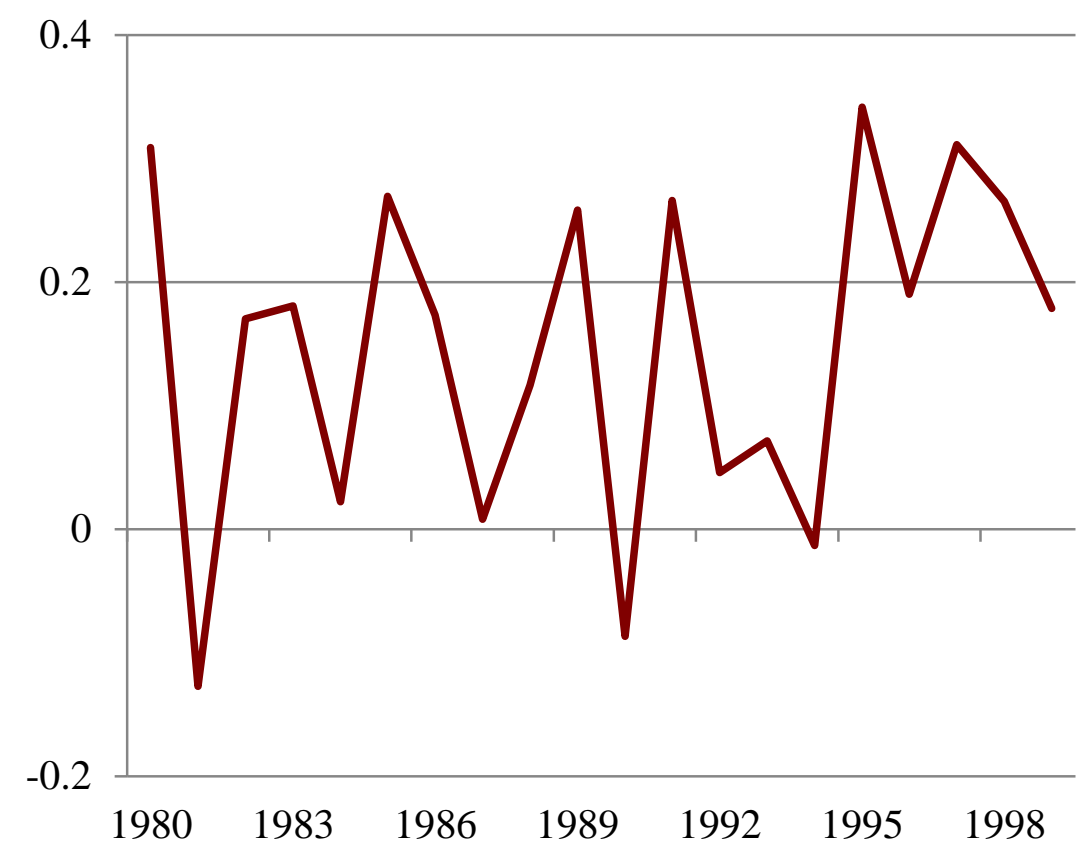

Source: Ibbotson Associates (2013).

The turning point came when labor saw the "gain" from investing in equities as increased benefits, not lower taxes. Labor specifically targeted a restoration of two key benefits lost in the 1983 reform: retirement on full benefits at age 60 with 30 years of service and, secondarily, more ample survivor benefits for widow(er)s. A catalyst that brought the two sides together was a September 17, 1998 Congressional hearing on a resolution that urged rail labor and management to negotiate improved benefit for the 250,000 widow(er)s the program supported - 30 percent of program beneficiaries. ${ }^{23}$ While the hearing focused on an expansion of benefits, a union representative was explicitly asked if to finance this expansion "he could support a change in Tier 2 investment policies to allow for equity investment to increase the rate of return on fund assets. 24

With both sides seeing the value of investing in equities, the negotiations began. What followed was the standard labor-management Kabuki dance, with each side sending out highly stylized messages, wary of giving too much and getting too little. Thus C.V. Monin,

\footnotetext{
${ }^{23}$ U.S. Department of Health and Human Services (1994). In 1993, retired and disabled workers accounted for 45 percent and spouses 55 percent of program beneficiaries.

${ }^{24}$ Salmon (2013), pp. 23-25.
} 
International President of the Brotherhood of Locomotive Engineers, wrote the Subcommittee on October 1:

The carriers indicated they wanted to discuss survivor benefits only as part of Labor/Management dialogue on all aspects of railroad retirement. My experience is that we can succeed in reaching a quick agreement to improve survivor benefits only if we stay focused on that issue and not muddy the waters by including all other issues.

However, Rail Labor stands ready to discuss any and all aspects of the railroad retirement system so long as those discussions are aimed at preserving and protecting the solvency and stability of our retirement program.

If the railroads truly want to open all aspects of the railroad retirement system to new Labor/Management dialogue, they should be aware that Rail Labor has a number of items to include on the discussion agenda.

To which Edward R. Hamberger, President and Chief Executive Officer of the Association of American Railroads responded on October 30:

As I stated in my testimony on September 17, AAR stands ready to discuss opportunities for improving our legislated retirement plan with rail labor and has made several overtures over the past two years to initiate such discussions ...

AAR and its member companies believe that out of such discussions might grow opportunities to lower the substantial payroll tax burden now carried by all railroad taxpayers, both employers and employees, while at the same time maintaining the value of the total package of benefits provided to covered participants. Only within the context of general discussions is this desirable outcome a real possibility. The importance of a broad consideration is heightened by the potential for major legislative changes in the Social Security system, which would inevitably affect Railroad Retirement. ${ }^{25}$

${ }^{25}$ Quoted in Salmon (2013), pp. 25-27. 


\section{NEGOTIATING REFORM}

On December 9, 1998 the two sides met and, for the first time, labor actively engaged in the process. Labor emphasized that benefit security was its paramount concern, expressed clear opposition to privatization, and put its benefit demands on the table. Labor also indicated its seriousness by asking for details about management's projections, informing management that it would be securing its own financial advisor, and asking that the Actuary at the Railroad Retirement Board be available as an impartial resource. ${ }^{26}$

The basic outline of a deal soon grew clear, and was dramatically different from management's original proposal. There would be no new private plan. Labor insisted that Railroad Retirement remain a government program with "statutory" benefits. But there would be equity investment. Railroad Retirement assets would be invested much like the assets in private employer plans. The assets would be managed by a nine-person board composed of three management, three labor, and three public trustees from the Railroad Retirement Board. And the expected gains from the higher return on equities would provide tax cuts for management and enhanced benefits for labor.

While the outline was clear, closing the deal was hardly straightforward. Labor and management had to agree on the size of the gain, how to divide it, and how to divide the risks that equity investment entailed. These issues were complex and interconnected. There was no guarantee that a deal could be struck that gave each side enough of what it needed. For the negotiations to proceed, each had to separate the other side's opening gambits from their basic demands, give up their own gambits and bargain in "good faith," and trust the other side to respond in kind. The negotiations began with management proposing and labor reacting. A tactically aggressive management proposal, put forward by the head of the NRLC at a June negotiations session, nearly derailed the process as labor felt a lack of "good faith" reciprocity. But labor regrouped, responded with counterproposals, and the negotiations went forward. ${ }^{27}$

Assessing the size and timing of the gain shifted fundamentally when privatization was taken off the table. The gain was no longer a reduction in the cost of the program at some point in the future. It would now be immediate or near-term tax reductions and benefit enhancements, consistent with maintaining an "adequate" Trust Fund balance. By the mid-1990s, assets in the

\footnotetext{
${ }^{26}$ Salmon (2013).

${ }^{27}$ Salmon (2013).
} 
Railroad Retirement Trust Fund had risen above four times annual benefit outlays for the first time since 1961 (Figure 1.5). The negotiators thus defined an "adequate" Trust Fund balance as assets at least equal to four times annual benefits. The ratio of assets to outlays was projected to rise over the next decade; turn down in the 2010s and 2020s, with railroad employment and payroll tax revenues falling faster than benefit outlays; then rise sharply as current beneficiaries died off. So the key question in determining the size of the "gain" became how much taxes could be cut or benefits increased and still have Trust Fund assets equal to four times benefit outlays in the 2010s and 20s - as "watermelon passed through the snake."

Figure 1.5. Trust Fund Account Benefit Ratios of Trust Fund Assets to Annual Benefit Outlays

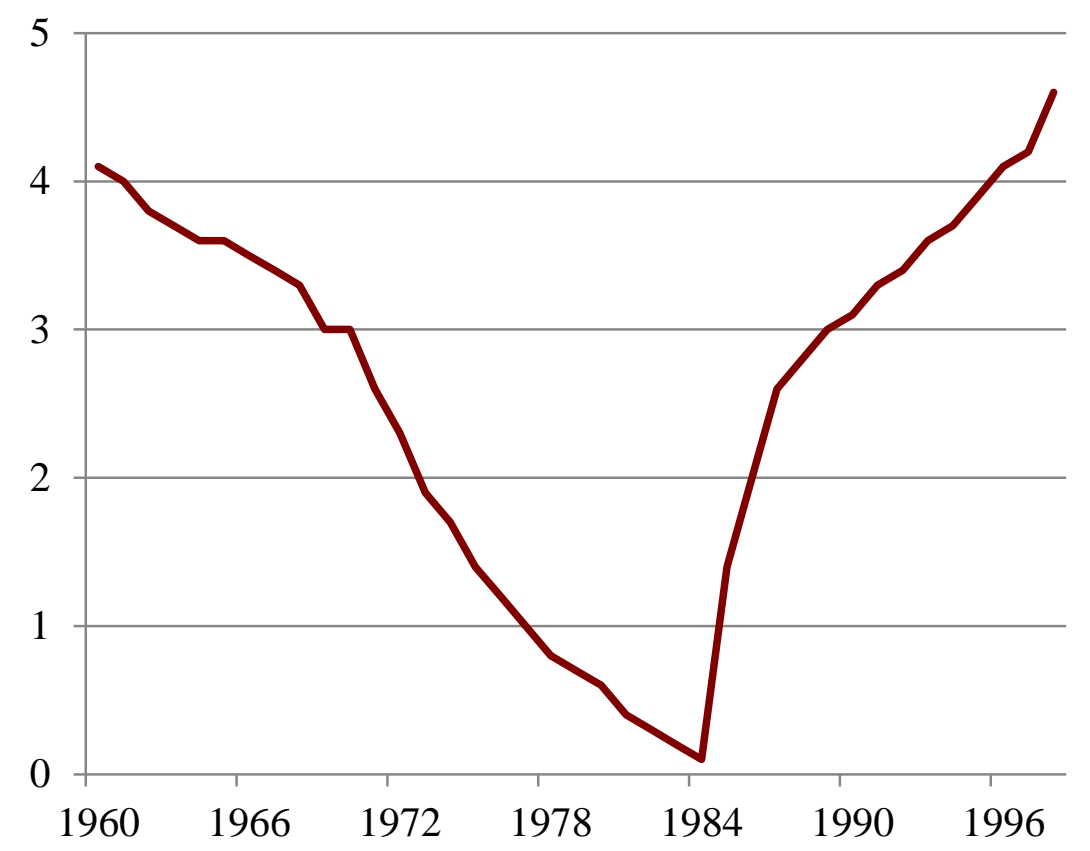

Source: U.S. Railroad Retirement Board Annual Reports, various years.

The next question was how to divide the gain. Each side made reasonable claims.

Management, noting it paid over 75 percent of the program's cost, sought a comparable share of the gain. Labor viewed the payroll taxes paid by the carriers as part of "labor compensation" and claimed the entire gain to avoid a cut in compensation. But before push came to shove, each side settled for a 50-50 split. ${ }^{28}$

${ }^{28}$ Salmon (2013) 
The negotiators then had to agree on the cost the desired benefit enhancements - and whether the gain would be large enough to pay for these enhancements. Most troublesome was the restoration of 60/30 - labor's key demand, by far the most expensive, and by far the most difficult to price. ${ }^{29}$ The cost, in terms of benefits paid and revenues lost, depended on how many workers would in fact retire early. These estimates were necessarily rough and predictable differences in these cost estimates complicated the negotiations. Labor also demanded a parallel extension of retiree health coverage, a benefit not provided by Railroad Retirement but included in the collectively bargained labor contract. Two unions also insisted on 55/30 - retirement on full benefits at age 55 with 30 years of service - an extremely expensive proposition. ${ }^{30}$ The carriers rejected 55/30 due to concerns about disruptive skill shortages, as well as cost. The remaining eleven unions desired 55/30, but recognized that the funds available were simply too small to afford it, without risking the stability of the system. They focused instead on the restoration of 60/30, since the Actuary's analysis demonstrated that this was an achievable goal without putting long term solvency at risk.

Then there was risk. The "tax adjustment mechanism," a key element in management's privatization designs, emerged as the critical risk-management tool. The mechanism, or "ratchet," had been the device in the privatization proposals that reduced the 21 percent payroll tax in the transition to a private plan. In the initial Union Pacific design of the late 1980s, it merely eliminated that 21 percent tax when the legacy Tier 2 program was "fully funded." "31 The 1995 TWG design modified the ratchet to kick in sooner and provide a more gradual transition to privatization. It would establish a target "account benefits ratio" - the ratio of Trust Fund assets to annual benefit outlays - and cut the payroll tax when the ratio exceeded that target. ${ }^{32}$ Now that Railroad Retirement would not be privatized but would invest in risky assets, the ratchet became the mechanism for keeping the account benefits ratio within a target band. Taxes would still be cut should Trust Fund assets exceed the band's upper bound, to be set at 6 times annual

\footnotetext{
${ }^{29}$ The enhanced Tier 2 survivor benefit was much less expensive, in part because the benefit was not indexed to inflation. Labor also demanded five-year vesting, which was now required of all private plans; but the cost of five year vesting was trivial.

${ }^{30}$ The two unions insisting on 55/30 were the Brotherhood of Maintenance and Way Employees and the Brotherhood of Locomotive Engineers and Trainmen.

${ }^{31}$ What tax or contribution would replace the 21 percent payroll tax to cover the "normal cost" of any remaining active legacy employees or to respond to adverse shocks to the funded status of the legacy program was not worked out in the early Union Pacific design.

${ }^{32}$ Tax Working Group (1994 and 1995).
} 
outlays. But taxes would rise should assets fall below a lower bound - the four times annual outlays the negotiators had agreed would be the minimum "adequate" Trust Fund balance. ${ }^{33}$

The negotiators then had to decide how this risk would be shared. Labor's position was simple. It insisted on the "division" of risk found in collectively bargained private plans, with management bearing all the risk and workers none. Labor was unwilling to see benefits cut or the tax on workers raised should the account benefits ratio fall below 4 times annual outlays. Management's position was also simple. It saw as a basic principle of finance a direct connection between risk and reward: if the carriers took all the risk, they should get all the reward. So management responded to labor's "no risk" demand with an offer where they took all the risk, got nearly all the gain. ${ }^{34}$

The ratchet was also the mechanism for reducing taxes after the watermelon had passed through the snake. To split the "gain" 50-50, the unions insisted that tax reductions also be split $50-50$ when the account benefits ratio rises above 6 times benefit outlays. ${ }^{35}$ Should the ratio subsequently fall, the unions agreed that the tax on workers could rise, up to the current 4.9 percent rate. But they insisted that reductions for the carriers cease should the tax on workers fall to 0 - setting a floor of 8.2 percent on management's payroll tax.

Recognizing that this risk-sharing issue was the key impediment to reaching a deal, the carriers ultimately agreed to labor's demands. But they insisted on a cap - that the ratchet could not push their tax above a specified level, to be set at 22.1 percent of payroll. So there would be a limit on how high or low the ratchet could set taxes - from a low of 8.2 percent, with the carriers paying the entire amount, to a high of 27 percent, with the workers paying 4.9 percent and the carriers the rest. On either side of these limits risk-management and the financing of Railroad Retirement would no longer be automatic, but require a renegotiation of the Railroad Retirement program.

Estimating the size of the gain, the cost of benefits, the risks to the program's finances, and the risks each party would bear, using a variety of reasonable assumptions, presented the

\footnotetext{
${ }^{33}$ By setting a four year reserve as the lower bound, the system was designed to have significantly higher reserves than found in national "pay-as-you-go" social security programs.

${ }^{34}$ This was the proposal, cited above, that the unions viewed as a sign of "bad faith."

35 There was some interest on labor's side to convert tax reductions the ratchet produced into higher benefits. But consensus opted for tax cuts, at least initially, to avoid introducing benefits the program might not be able to maintain. All parties agreed that this was something labor and management could renegotiate at a later date.
} 
negotiators with an exceedingly confusing "Rubik's cube"36 of options. They would need to decide on various technical details, such as when the new program with its lower taxes and higher benefits would start, how the account benefits ratio would be measured, and how the ratchet would raise and lower taxes. The later the program would start, the greater the program's Trust Fund assets and projected asset income. To avoid controversies and sharp changes in the payroll tax, the negotiators agreed to measure the account benefit ratio as the average ratio over a number of trailing years. The finances of pension plans were typically guided by forwardlooking actuarial projections, not backward-looking trailing ratios. But trailing ratios were objective data while actuarial projections involved judgments that could invite disputes. Basing tax rates on actuarial projections, moreover, could also raise Constitutional issues as the executive branch, not Congress, would then be setting tax rates. ${ }^{37}$ The ratchet also based tax rates on multi-year averages to dampen volatility: neither management nor labor wanted a system where taxes could change each year. Both saw averaging as affecting the timing of taxes needed to fund the program - primarily taxes on the carriers, which bore the primary burden for funding Railroad Retirement - not the obligation to fund the system.

The availability of the Railroad Retirement Actuary as an impartial resource was a critical contributor to success of the negotiations. The Actuary ran projections of different "Rubik's cube" combinations that both sides could accept - assuming both accepted the assumptions the Actuary used. The negotiations were also greatly simplified with the announcement, in the Actuary's August 1999 annual "Section 502" report to the Railroad Retirement Board, that railroad employment was, and would likely be, higher than previously projected. Rail employment was hard to predict, with projections ranging from a mild to a dramatic decline. With payroll taxes as the dominant source of Railroad Retirement revenues, assessments of the size of the "gain" and the risks to the program were critically dependent on the Actuary's employment projections. The updated August 1999 projections now indicated that a deal could be reached.

The Actuary's projections had never shown a 50-50 split of the gain could support 55/30 - retirement on full benefits at age 55 with 30 years of service - except assuming very low rates of early retirement. Projections based on the August 1999 data did not change that assessment.

\footnotetext{
${ }^{36}$ Salmon (2013).

${ }^{37}$ Interview with Randy Weiss.
} 
They did, however, indicate that the program could support 60/30 in most scenarios if the transition were delayed just a few years. Labor would get its benefit enhancements and the carrier a 3 percent reduction in their payroll tax. Stress tests showed these reforms capable of negotiating the "watermelon in the snake" using the Actuary's "optimistic" projection of railroad employment (Figure 1.6); and likely to produce enough revenue to pay promised benefits using the "intermediate" employment projection. As rail employment had tended to conform to the Actuary's "optimistic" projections, the negotiators were comfortable with these results.

Figure 1.6. Projected Account Balances Under Industry Reform Proposal

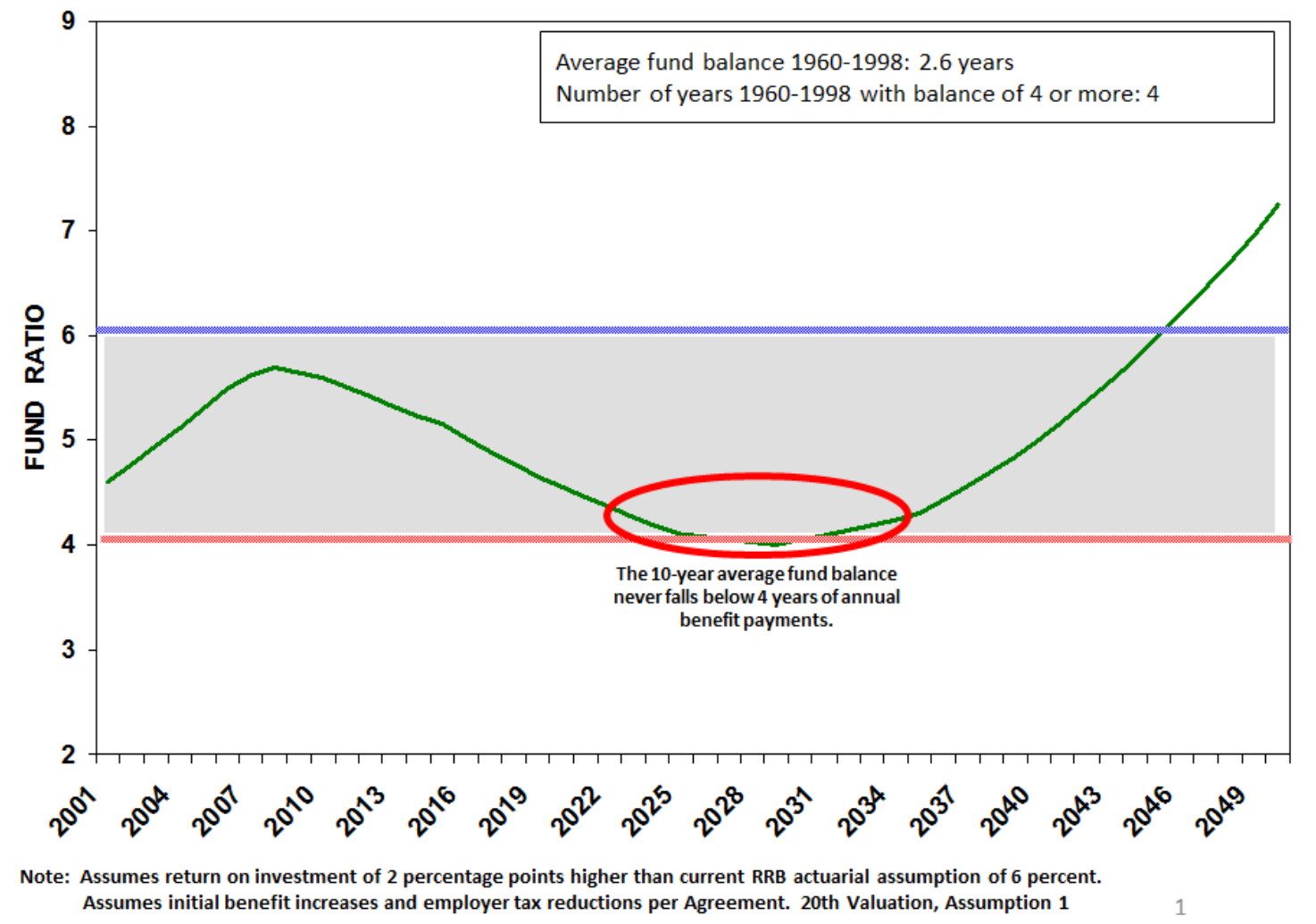

Source: John Salmon, private communication.

The Actuary was not so sanguine. By training, actuaries tend to be very cautious and estimates using the "pessimistic" employment projection did not do well. That projection had rail employment falling nearly two-thirds by the middle of century, to a seemingly implausible level well below 100,000. Neither Congress nor the unions, however, would sign off on a deal that the Actuary thought too risky. So an urgent negotiation ensued. To avoid sharp changes in tax rates, the negotiators' had designed a ratchet that measured the account benefits ratio as the 
average ratio over the previous 10 years, which slowed the ratio's rise as the watermelon entered the snake. To make the mechanism more responsive, a revised proposal changed the size of the tax increments to the schedule shown in Figure 1.7. The ratchet still failed to produce sufficient revenues in stress tests using the "pessimistic" employment projection. But it gave management, labor, and Congress more time to respond to shortfalls identified in the required annual five-year projections of the program's finances. And this was enough for the Actuary to allow the plan to proceed.

Figure 1.7. The Tax Adjustment Ratchet, Railroad Retirement Payroll Tax Based on 10-Year Average Ratio of Assets to Annual Outlays

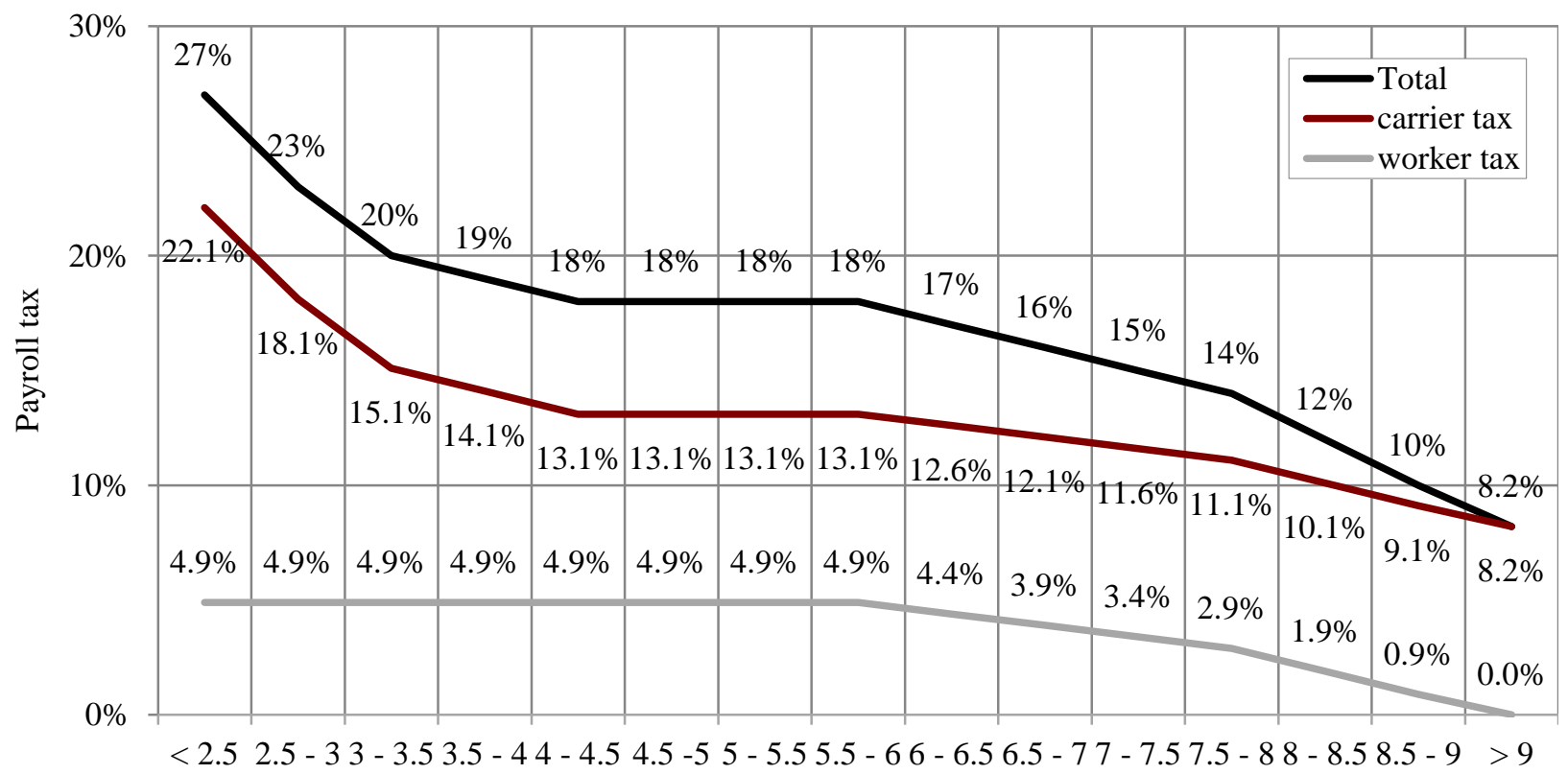

Average account benefit ratio

Source: U.S. Senate Republican Policy Committee (2001).

So the deal on the table was set. Labor would get early retirement on full benefits with 30 years of service, enhanced health insurance for early retirees, enhanced survivor benefits, and five year vesting. Two unions continued to hold out for 55/30. But the other eleven decided to go forward without the two holdouts.

The management negotiators reviewed the deal with senior management, outlining the benefits and risks in a reformed Railroad Retirement program. The deal would cut the carrier's payroll tax from 16.1 to 13.1 percent; their tax would likely rise as the watermelon passed through the snake, though not above 22.1 percent; then likely fall to about 10 percent or less by 
the middle of the twenty-first century. Tax rates would also change automatically, without contentious negotiations with labor or the troublesome involvement of Congress. The carriers would bear all the risk of funding shortfalls. But the most likely cause of such shortfalls was a sharper than expected employment decline. So the carriers' total tax (employment $\mathrm{x}$ average earnings $\mathrm{x}$ the payroll tax rate) would not rise nearly as much as the employment decline and would offset the tax increase. To the degree employment declines reflect increased efficiency and profitability, the ratchet in fact reduced the carriers' risk, adjusting the tax rate in line with the carriers' ability to pay. And without reform the carriers would not get the immediate tax reduction and higher expected returns on equities. So the carriers also agreed to go forward.

\section{INSIDE THE BELTWAY}

With a deal in hand, labor and management now jointly went to Congress to win enactment of their agreement. ${ }^{38}$ Congress found various elements of the new program attractive. The ratchet's risk-management properties helped assuage concerns about investing "government" assets in equities. It also allowed Congress to distance itself from setting Railroad Retirement taxes and benefits, clearly a poor use of Congressional time and resources. Getting the deal enacted, however, proved difficult. There was concern that the proposed bill lowered the age rail workers could claim full benefits while Social Security's Full Retirement Age was rising, and many reformers urged an even higher retirement age. The major resistance, however, came from the right, from Republican lawmakers and pundits who characterized the reform as a dangerous and ill-advised political boondoggle.

Viewing Railroad Retirement as a private plan, these critics saw raising benefits and cutting taxes as a crazy response to "a $\$ 40$ billion unfunded liability." 39 Viewing Railroad Retirement as a government program, they saw reform as busting the federal budget, with higher benefits and lower taxes adding $\$ 7$ billion to deficit over the next ten years. They also considered the sale of $\$ 15$ billion in government bonds, with the proceeds used to purchase securities of equal value, as a deficit-widening expenditure. The rail industry would successfully argue that using the proceeds from the bond sales to purchase securities was "a means of

\footnotetext{
${ }^{38}$ This was the typical pattern for making changes in the Railroad Retirement program. Salmon (2013), p. 61.

${ }^{39}$ Novak (2001a and 2001b)
} 
financing," not an "expenditure," and thus not a budgetary item. But the critics viewed this treatment as a politically motivated ruse. ${ }^{40}$

The sharpest complaints focused on the proposed investment in equities. The critics claimed that equity investment was how the program would "make up for lost revenue [and increased benefits]." And they viewed this "arbitrage" - selling bonds to buy stocks, effectively "borrowing money from the public and then getting a higher rate of return through private investment" - as pixie dust that would come to no good. Most troublesome, it would open "a brave new world for managers of government trust funds" 42 and the "political appointees and government bureaucrats" who controlled these funds. ${ }^{43}$

Given the modest importance of Railroad Retirement in the nation's political agenda, the attack was far more intense than one might expect. The issue, however, was Social Security, not Railroad Retirement. Reforming Social Security was a major initiative of the new Bush Administration. The Administration's key proposal was to allow workers to direct a portion of their payroll taxes to personal retirement savings accounts in exchange for a reduction in their future Social Security retirement benefits. This would shift the assets financing future Social Security-equivalent retirement income from the government bonds in the Social Security Trust Fund to equities and other securities, as in 401(k)s and employer pension plans. Proponents argued that this would increase national saving and raise the return on "Social Security" assets. This, of course, was precisely what the proposed shift in Railroad Retirement assets would do. So the problem was not so much "arbitrage" and pixie dust, but how retirement assets would be managed.

The Democrats under President Clinton had proposed investing Social Security assets in equities, using the Social Security Trust Fund. The Republicans viewed this arrangement, and the Railroad Retirement proposal that seemed so similar, as "a dangerous investment scheme." The dangers were both financial and political. "Giving bureaucrats the power to invest huge amounts of money in the stock market would create a fundamental conflict of interest between the long-term needs of future retirees and short-term political goals. If this model were extended

\footnotetext{
${ }^{40}$ RRSIA Section 105(c); not all criticism came from the right. The Washington Post, in a September 30, 2000 editorial on "The Railroad Bailout," endorsed the critics' position that the industry proposal would be "a loss to the taxpayers" and that "analysts warn that even if the investments pan out, in the long-run the arrangement is unsustainable."

${ }^{41}$ John (2000).

${ }^{42}$ Novak (2001a)

${ }^{43}$ John (2000).
} 
to Social Security's trust funds, the door would open for government ownership of a significant portion of the economy." 44 According to Alan Greenspan, it would then be "almost impossible to insulate investment decisions from political interference." ${ }^{, 5}$ A key principle in the Bush White House effort to reform Social Security was that "Government must not invest Social Security funds in the stock market" and it told congressional leaders that in the proposed legislation for reforming Railroad Retirement "the reserves in a Federal retirement trust fund would be invested in the private equities market, and the proceeds from those investments would be used to pay for federal entitlement benefits. ${ }^{, 46}$

The Republican leadership thus saw the stakes as enormously high. Simple backbenchers, however, were more attuned to the support for reform from rail labor and management. Union and carrier representatives made joint visits to key Congressmen and Senators. According to Joel Parker, a lead labor negotiator, the unions organized the "one of the biggest lobbying efforts by the rank-and-file in labor history," with members receiving a steady stream of communications singing the virtues of reform and mailers to be sent to Congressmen and Senators. Given the popularity of 60/30 and enhanced widow(er)'s benefits, it did not take much to motivate the rank-and-file. ${ }^{47}$

The House passed legislation in September 2000 for what would become the Railroad Retirement and Survivor's Improvement Act in 2001. The legislation included numerous safeguards against political intervention in Railroad Retirement investment decisions, discussed in the next discussion paper. But "government assets" would still be invested in equities and the Republican leadership, which controlled the Senate, was able to block the bill. The House passed essentially the same legislation in 2001 by a vote of 384 for and 33 against, and the Senate leadership again blocked the bill. What broke the logjam was the decision by Senator James Jeffords of Vermont to quit the Republican Party, become an independent, and caucus with the Democrats. That gave Democrats control of the Senate and its schedule, which allowed the bill to come up for a vote. The key vote was the vote to end a filibuster by Republican leaders, and widely understood as a vote on the legislation itself. Voting "yes" was politically expedient, as it made rail workers, retirees, and rail management happy. So once passage

\footnotetext{
${ }^{44}$ John (2000).

${ }^{45}$ John (2000).

${ }^{46}$ U.S. Senate Republican Policy Committee (2001) p.7; Bush (2001).

${ }^{47}$ Interview with Joel Parker. Salmon (2013) pp. 62 ff.
} 
seemed assured, even many Republican Senators voted to end the filibuster. Reform was then enacted with overwhelming support: 90 votes for and 9 against. President Bush, unwilling to veto this clear "will of Congress," signed the Railroad Retirement and Survivor's Improvement Act into law on December 21, 2001. ${ }^{48}$

\footnotetext{
${ }^{48}$ National Railroad Retirement Trust (2002). See Salmon (2013) pp. $60 \mathrm{ff}$. for an insightful narration of the
} enactment process. 


\section{References}

Association of American Railroads. 2011. "The Impact of the Staggers Rail Act of 1980." Washington, DC.

Bush, George W. 2001. Remarks by the President in Social Security Announcement. Available at: http://www.ssa.gov/history/gwbushaddress2.html.

Caves, Douglas W., Laurits R. Christensen, and Joseph A. Swanson. 2010-11. "The Staggers Act, 30 Years Later." Regulation 28: 28-31.

Commission on Railroad Retirement Reform. 1990. Final Report. Washington, DC: Commission on Railroad Retirement Reform.

Ibbotson Associates. 2013. SBBI Classic Yearbook 2013: Market Results for Stocks, Bonds, Bills, and Inflation 1926-2010. Chicago, IL: Morningstar, Inc.

Interview with Bernie Gutschewski. January 11, 2011.

Interview with Joel Parker. January 29, 2012.

Interview with James Hixon. January 6, 2012.

Interview with Randy Weiss. April 10, 2013.

John, David. 2000. "Railroad Retirement Investment Threatens Social Security Reform." Executive Memorandum on Retirement Security \#698. Washington, DC: The Heritage Foundation.

National Railroad Retirement Trust. 2002. 2nd Annual Management Report for Fiscal Year 2002. Available at http://www.rrb.gov/pdf/nrrit/2covrpt.pdf.

Novak, Robert. 2001a. “The Great Train Robbery.” Available at: http://townhall.com/columnists/robertnovak/2001/07/30/the_great_train_robbery/.

Novak, Robert. 2001b. "Elephant in the Senate." Available at: http://townhall.com/columnists/robertnovak/2001/09/03/elephant_in_the_senate.

Sass, Steven A. 1997. The Promise of Private Pensions. Cambridge, MA: Harvard University Press.

Salmon, John. 2013. "The Creation of the National Railroad Retirement Investment Trust: Improving Railroad Retirement for Labor, Management and Beneficiaries: 1995-2002." MSS.

Stover, John F. 1997. American Railroads (2nd ed.). Chicago, IL: University of Chicago Press. 
Tax Working Group. 1994. Memorandum to Gremillion. Provided by John Salmon.

Tax Working Group. 1995. Railroad Retirement: A Proposal for Reform. PowerPoint Presentation Notes. Provided by John Salmon.

The Washington Post. 2000. “The Railroad Bailout.” Editorial. September 30, 2000.

U.S. Department of Health and Human Services. 1994. "Section 4. Railroad Retirement System." Available at: http://aspe.hhs.gov/94gb/sec04.txt.

U.S. Railroad Retirement Board. 2009. Railroad Retirement Handbook. Chicago, IL. . 2010. "The Railroad Retirement System: Its First Seventy-Five Years." Chicago, IL. Available at: http://www.rrb.gov/pdf/opa/pub_1004.pdf. . Various Years. Annual Report. Chicago, IL.

U.S. Senate Republican Policy Committee. 2001. H.R. 1140 S Railroad Retirement and Survivors' Improvement Act of 2001. Washington, DC: U.S. Senate Republican Policy Committee.

Whitman, Kevin. 2008. "Overview of the Railroad Retirement Program." Social Security Bulletin 68(2): 41-51.

Winston, Clifford. 2006. "The Transformation of the U.S. Rail Industry," in Gines de Rus and Jose A. Gomez-Ibanez, eds., Railway Reform and Competition. Cheltenham, UK: Edward-Elgar Press. 


\section{RECENT WORKING PAPERS FROM THE CENTER FOR RETIREMENT RESEARCH AT BOSTON COLLEGE}

How Do the Disabled Cope While Waiting for SSDI?

Norma B. Coe, Stephan Lindner, Kendrew Wong, and April Yanyuan Wu, June 2013

The Impact of Population Aging and Delayed Retirement on Workforce Productivity Gary Burtless, May 2013

Does Access to Health Insurance Influence Work Effort Among Disability Cash Benefit Recipients?

Norma B. Coe and Kalman Rupp, April 2013

How Will Older Workers Who Lose Their Jobs During the Great Recession Fare in the Long-Run?

Matthew S. Rutledge, Natalia Orlova, and Anthony Webb, March 2013

Can Long-Term Care Insurance Partnership Programs Increase Coverage and Reduce Medicaid Costs?

Wei Sun and Anthony Webb, March 2013

SSI for Disabled Immigrants: Why Do Ethnic Networks Matter?

Delia Furtado and Nikolaos Theodoropoulos, February 2013

The Use of VA Disability Benefits and Social Security Disability Insurance Among Veterans

Janet M. Wilmoth, Andrew S. London, and Colleen M. Heflin, February 2013

How Does the Composition of Disability Insurance Applicants Change Across Business Cycles?

Norma B. Coe and Matthew S. Rutledge, February 2013

The Economic Implications of the Department of Labor's 2010 Proposals for BrokerDealers

Alicia H. Munnell, Anthony Webb, and Francis M. Vitagliano, January 2013

What Is the Long-Term Impact of Zebley on Adult and Child Outcomes?

Norma B. Coe and Matthew S. Rutledge, January 2013

Sticky Ages: Why Is Age 65 Still a Retirement Peak?

Norma B. Coe, Mashfiqur R. Khan, and Matthew S. Rutledge, January 2013

All working papers are available on the Center for Retirement Research website (http://crr.bc.edu) and can be requested by e-mail (crr@bc.edu) or phone (617-552-1762). 